\title{
Kasvipeitteisyyden viljelyteknologia muuttuvassa ilmastossa- jatkuvat mittaukset kasvipeitteisyydestä johtuvien ilmiöiden selvittämiseksi
}

\author{
Ossi Knuutila ${ }^{1)}$, Mikko Hautala ${ }^{1)}$, Antti Ristolainen ${ }^{2)}$, Ansa Palojärvi $^{2)}$, Laura Alakukku ${ }^{1)}$ \\ ${ }^{1)}$ Maataloustieteiden laitos, 00014 Helsingin yliopisto, ossi.knuutila@ helsinki.fi, \\ mikko.hautala@helsinki.fi,laura.alakukku@helsinki.fi \\ ${ }^{2)}$ MTT Kasvituotannon tutkimus,31600Jokioinen,antti.ristolainen@mtt.fi,ansa.palojarvi@mtt.fi
}

\section{Tiivistelmä}

Maataloustuotantoon kohdistuu suuria ympäristöhaasteita. Valtakunnallisessa vesiensuojelussa on tavoitteena, että maatalouden kuormitus vähenisi kolmanneksen verrattuna vuosien 2001-2005 kuormitukseen vuoteen 2015 mennessä. Samaan aikaan maatalouden tulee myös sopeutua ilmastonmuutokseen.

Suurin osa maatalouden vesistökuormituksesta muodostuu kasvukauden ulkopuolella. Valuntahuiput ajoittuvat keväällä lumen ja roudan sulamiseen ja syksyn sateisiin. Tulevaisuudessa ravinnekuormituksen hallinta on entistä haastavampaa, mikäli syksyt muuttuvat nykyistä sateisimmiksi ja talvet leudommiksi, kuten nykyisten ilmastonmuutosennusteiden perusteella voidaan olettaa.

Talviaikainen kasvipeitteisyys suojaa maan pintaa ja sen on todettu vähentävän savimaiden eroosiota ja partikkelifosforin huuhtoutumista. Kevätkylvöisten kasvien viljelyssä kasvukauden ulkopuolinen kasvipeitteisyys voidaan toteuttaa sekä vähentämällä syysmuokkausta $(\mathrm{mm}$. kevennetty muokkaus, suorakylvö säkeen keväällä) että lisäämällä viljelykiertoon monivuotisia kasveja.

Muokkausta kevennettäessä edellisen vuoden kasvustojäte voi mm. hidastaa maan lämpenemistä ja kuivumista keväällä sekä luoda suotuisat olosuhteet vaikeuttaa maa- ja kasvijätelevintäisille kasvitaudeille. Useimmiten maassa on kuitenkin jossain määrin luontaista kykyä estää taudinaiheuttajien kehittymistä ja kasvua. Syynä ovat muut maaperän mikrobit: mikrobiston monimuotoisuuden sinänsä on todettu vahvistavan maan kykyä tukahduttaa sienitauteja. Maaperän mikrobiston koostumuksen ratkaisevana tekijänä on viljelytekniikka, joka vaikuttaa maamikrobien ravintoon ja elinympäristön olosuhteisiin.

Vuonna 2009 aloitettiin hanke 'Tuotannon kestävyys muuttuvissa ilmasto-oloissa - teknologiset ratkaisut ja maaperäbiologisten ekosysteemipalvelujen hyödyntäminen (SUCCESS)', jonka tavoitteena on kehittää innovatiivistä ja käytännön peltoviljelyyn soveltuvaa maatalouden ympäristöteknologiaa peltojen kasvipeitteisyyden lisäämiseksi samalla hyödyntäen maaperämikrobiston ekosysteemipalveluja tautimikrobien tukahduttamiseksi luontaisin menetelmin ja kasvijätteen toivotunlaiseksi hajotukseksi. Hankkeessa on monitieteinen tutkimusryhmä MTT:n ja Helsingin yliopiston tutkijoita maatalouden ympäristöteknologiasta, ympäristöbiotekniikasta, biologiasta ja mikrobiologiasta.

Posterissa esitellään SUCCESS hanke sekä siinä rakennettu jatkuvatoiminen mittausjärjestelmä maan ja maa-ilma - rajapinnan ominaisuuksien tutkimiseen. Mittausjärjestelmät on pystytetty kahdelle koealueelle; monokulttuuri ja viljelykierto kokeisiin. Mittauksilla vertaillaan kyntö ja suorakylvölohkojen olosuhteissa tapahtuvia muutoksia vuoden ympäri. Lisäksi kerrotaan mittaustulosten hyödyntämisestä mallituksessa ja menetelmäkehityksessä.

Asiasanat: suorakylvö, kyntö, automaattimittaukset, maaperämikrobisto, kasvitaudit 


\section{Johdanto}

Suomessa peltomaista huuhtoutunut kiintoaines tunnustetaan merkittäväksi syyksi vesistöjen fosforikuormitukselle. Suurin osa maatalouden eroosio- ja ravinnekuormituksesta syntyy kasvukauden ulkopuolella (Puustinen et al., 2007, Turtola et al., 2007). Yleensä valuntahuiput ovat kevään lumen sulamisen ja syksyn sateisen kauden aikana. Ravinnekuormituksen kurissapitäminen on tulevaisuudessa nykyistäkin haastavampaa, mikäli syksyt muuttuvat sateisimmiksi ja talvet leudommiksi, kuten on ennustettu (IPCC, 2007).

Suomen maatalouden ympäristöohjelman avulla viljelijöitä kannustetaan lisäämään talviaikaista kasvipeitteisyysalaa eroosio- ja ravinnekuormituksen hillitsemiseksi. Kasvipeitteisyys vähentää kuormitusta parantamalla mm. pintamaan murujen kestävyyttä, kun maan orgaanisen aineksen pitoisuus kasvaa. Suuriosa uudesta kasvipeitteisestä alasta on muodostunut Etelä- ja Lounais-Suomen savimaille, joilla viljellään yksivuotisia viljelykasveja. Tästä alasta muokataan vuosittain $75-85 \%$. Kevennetty muokkaus, suorakylvö ja monivuotiset nurmet on havaittu tehokkaiksi eroosiontorjuntakeinoiksi boreaalisella alueella (Børresen ja Uhlen, 1991; Skøjen et al., 1995; Puustinen et al., 2007). Viimeisten vuosien aikana suomalaiset viljelijät ovat kasvavissa määrin ottaneet käyttöön eroosiota torjuvia viljelymenetelmiä. Esimerkiksi suorakylvetty ala oli vuonna 1998 vain muutamia kymmeniä hehtaareja, kun vuonna 2008 ala oli noin 160000 ha (13\% puitavien kasvien kokonaisalasta; TIKE, 2009).

Luontoa säästävät viljelymenetelmät tuovat mukanaan omat haasteensa. Suurimman haasteen aiheuttaa pinnalle jäänyt kasvustojäte, joka voi haitata viljelyä sekä teknisesti että biologisesti. Pinnalla olevan kasvustojätteen vuoksi sänkimaa kuivuu ja lämpenee muokattua maata hitaammin, mikä viivästyttää osaltaan kasvua. Samalla myös maa- ja kasviperäisten kasvitautien elinolosuhteet pysyvät muokattua maata suotuisempina kasvukauden aikana.

Muokkausta vähentävien viljelymenetelmien käytön ympäristöhyötyä pienentää mahdollisesti lisääntyvä rikkakasvien ja kasvitautien torjuntatarve. Maan mikro-organismien on havaittu kuitenkin tuottavan ekosysteemipalveluita, jotka edesauttavat maan kykyä tukehduttaa sienitauteja. Tietyn paikan tautisupressiivisuuteen vaikuttavat: muokkaustapa, viljelykasvi, viljelykierto ja maan orgaanisen aineksen pitoisuus (Janvier et al., 2007). Yleisen mikrobiaktiivisuuden ja mikrobiston monimuotoisuuden on todettu olevan yhteydessä maan tautisupressiivisuuteen (de Boer at al., 2003). Muokkauksen keventyessä on selkeä tarve löytää optimaalisia viljelykombinaatioita, jotta maan mikrobeja voitaisiin käyttää hyödyksi nykyistä tehokkaammin.

Vaikka maan ominaisuudet ja maa-ilma -rajapinnan mikroilmasto vaikuttavat kiistatta mikrobien elinolosuhteisiin, näiden ominaisuuksien ja tautisupressiivisuuden tai kasvijätteen hajoamisen välistä riippuvuutta on harvoin tutkittu laaja-alaisesti kehitettäessä mikrobeja hyödyntävää muokkausteknologiaa. Mikrobiologisten prosessien kannalta elinolosuhteiden muutokset kaikkina vuodenaikoina ovat tärkeitä. Nykyisin on mahdollista mitata jatkuvatoimisilla mittaussysteemeillä maan ja ilman olosuhteita kuvaavia suureita ympäri vuoden. Jatkuvia automaattimittauksia on kuitenkin hyödynnetty harvoin mikrobiologisissa tutkimuksissa.

Sopeuduttaessa ilmastonmuutokseen talviaikaisen kuormituksen hallinta vaatii uusia, nykyistä tehokkaampia biologis-teknologisia vesiensuojelukeinoja. Vuonna 2009 alkaneessa 'Tuotannon kestävyys muuttuvissa ilmasto-oloissa - teknologiset ratkaisut ja maaperäbiologisten ekosysteemipalvelujen hyödyntäminen (SUCCESS)' - hankkeessa tutkitaan kasvustojätteen määrän ja laadun vaikutusta maailma- rajapinnan olosuhteisiin sekä maan mikrobistoon muokkauksen keventyessä. Tavoitteena on kehittää innovatiivista käytännön peltoviljelyyn soveltuvaa ympäristöteknologiaa, joka vähentää kasvitautien kemiallisen torjunnan tarvetta ja lisää peltojen kasvipeitteisyyttä kasvukauden ulkopuolella yksivuotisten kasvien viljelyssä.

\section{Monitieteinen hanke}

Tutkimus koostuu kolmesta osahankkeesta. Osahanke 1 tutkii kasvipeitteisyyden ja muokkausintensiteetin vaikutuksia maan fysikaalisiin ominaisuuksiin, muokkaantuvuuteen ja mikrobien elinolosuhteisiin. Muut osahankkeet keskittyvät maan tautisupressiivisuuden ja kasvustojätteen hajotusmekanismien selvittämiseen.

Tutkimuksessa hyödynnetään kahta pitkäaikaista muokkaus- ja viljelykiertokoetta. Peltokokeet sijaitsevat Maa- ja elintarviketalouden tutkimuskeskuksen (MTT) mailla Jokioisissa. Kenttäkokeet ovat pääosin 
savimailla (saves (partikkeli koko $<0,002 \mathrm{~mm}$ ) $>40 \%$ ). Valtaosa Suomen savimaista sijaitsevat Etelä ja Lounais-Suomessa. Sama alue on myös tärkein yksivuotisten viljelykasvien viljelyalue.

\section{Jatkuvatoimiset automaattimittaukset ympäri vuoden}

Osaprojektin 1 yhtenä oleellisena osana on matemaattinen mallintaminen. Hankkeessa kehitetään fysikaalinen malli, jonka avulla on mahdollista mallintaa maa-ilma rajapinnalla tapahtuvia ilmiöitä rajallisin lähtötiedoin. Hankkeessa keskitytään erityisesti kasvukauden ulkopuolisten ilmiöiden mallitukseen. Mallin luontia ja validointia varten tarvitaan tietoa, miten mallinnettavat suureet käyttäytyvät vuoden aikana.

Hankkeessa mitataan maan ja maa-ilma-rajapinnan olosuhteita jatkuvatoimisesti ympäri vuoden kynnetyssä ja sänkimaassa (suorakylvö keväällä). Hankkeessa on rakennettu neljä identtistä mittausasemaa (kuva 1), joihin liitetään olemassa olevia sääasemia. Mittaukset aloitettiin kesällä 2009 ja ne jatkuvat vuoteen 2011. Mittausasemille on yhteys langattomilla radiomodeemeilla, jotka mahdollistavat kahdensuuntaisen tiedonsiirron. Yhteenlaskettu antureiden määrä on yli kaksisataa. Instrumentointi pyrittiin suunnittelemaan niin, että maan mikrobiaktiivisuutta pystyttäisiin seuraamaan reaaliaikaisesti ympäri vuoden. Mittausasemat sijaitsevat kahdella savimaan koekentällä, joiden etäisyys toisistaan on $\mathrm{n} .1 \mathrm{~km}$. Kokeet ovat pitkäaikaiskokeita, joissa toisessa viljellään ohraa monokulttuurissa ja toisessa on monipuolinen yksivuotisten kasvien viljelykierto. Molemmilta koekentiltä valittiin suorakylvö-kyntö ruutupari, joissa mittaukset tehdään.

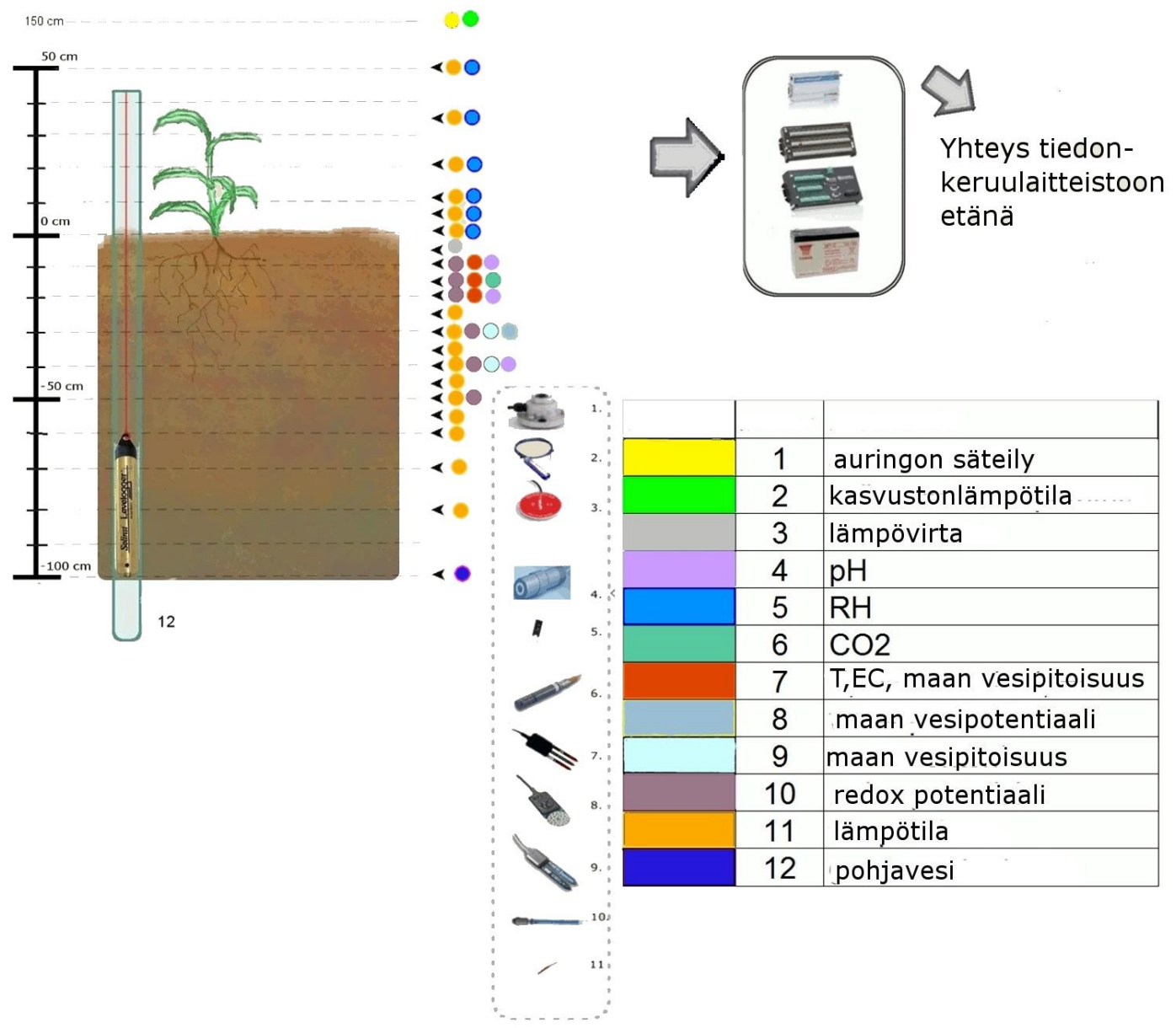

\section{Kuva 1. Mittausaseman kokoonpano.}

Maasta tehtävien mittausten lisäksi koekentiltä määritetään kasvuston kehitysasteet, kasvitaudit ja biomassan ravinteiden-otto. Kenttämittauksia tukevissa laboratoriomittauksissa määritetään koemaiden fysikaalisten ominaisuuksien vaihtelua. Laboratoriossa tutkitaan myös vakio-olosuhteissa kasvustojätteen määrän ja laadun vaikutusta maan olosuhteisiin sekä mikrobiston aktiivisuuteen. 


\section{Kirjallisuus}

Børresen, T. \& Uhlen, G. 1991. Soil erosion and phosphorus losses in winter surface runoff in field lysimetes at Ås 1989-1990. Norsk landbrukforskning 5: 47-54.

Butler, P.J., \& Haygarth, P.M. 2007. Effects of tillage and reseeding on phosphorus transfers from grassland. British Society of Soil Science 23: 71.81 .

de Boer W, Verheggen, P., KlainGunnewiek, P.J.A., Kowalchuk, G.A., \& van Veen, J.A. 2003. Microbial Community Composition Affects Soil Fungistasis. Applied Enviromental Microbiology 69:835-844.

IPCC. 2007. Climate Change 2007: Synthesis Report. 52p. Luettavissa: <www.ipcc.ch/pdf/assessmentreport/ar4/syr/ar4_syr.pdf

Janvier C, Villeneuve, F., Alavouvette, C., Edel-Hermann, V., Mateille, T. \& Steinberg, C. 2007. Soil health through soil disease suppression: whichj strategy from descriptors to indicators? Soil Biology \& Biochemistry 39:123.

Skøien,S, Børresen, T., Lundekvam, H. \& Uhlen, G. 1995. Effects of plant cover and tillage on soil erosion and phosphotus losses in surface runoff. In: Linden, B. (ed.) Proc. NJF seminar no. 245. The use of catch or cover crops to reduce leaching and erosion. NjF-utredning/rapport nr 99. Knivsta, Sweden, 3-4 October 1994. pp.142-147.

Tike.. 2009. Matilda. www.matilda.fi/servlet/

Turtola, E., Alakukku, L., Uusitalo, R., \& Kaseva, A. 2007. Surface runoff, subsurface drainfflow and soil erosion as affected by tillage in a clayey Finnish soil. Agricultural and Food Science 16: 332-351. 